\title{
V The Periphery of the Network: Friends of Commission
}

In constructing a family image in early Renaissance Florence, as well as contemporary Hungary, commissions to skilled artisans served to build up the fame of the family, as well as to preserve its memory. ${ }^{1}$ In her analysis on the artistic patronage of the Nasi and the Del Pugliese families, back then both new to Florentine society, Jill Burke has shown the ways they attempted to create a public image for their lineages by means of visual representation. ${ }^{2}$ Even though the Scolari was an ancient lineage, which traced ancestry back three centuries, because of their lost status and influence, they needed to reintroduce themselves to the Florentine ruling elite. Their commissions of objects and buildings testify to the fact that the three elder Scolaris' concern in enforcing their family's identity provided a basis for cooperation, or maybe even friendship, with several significant Florentine artisans. Among them were leading goldsmiths, architects, and painters, who, by their innovative spirit, contributed considerably to the development of the early Renaissance material culture.

Artisans in Florence typically did not belong to the same social strata as merchants. Though the most prestigious among them might have had family names that were developed before the studied period, the lack of their political influence as well as their modest family patrimony did not entitle them to intermarry with the mercantile elite. ${ }^{3}$ Only exceptions like the Gaddi family, which had both international merchants and important artisans among its members, might have maintained nuptial ties to other merchant families. ${ }^{4}$

However, artisans became part of a similarly complex network of commissions, also including those merchants and their families who wished

1 Art, Memory and Family. Jékely, 'Die Rolle der Kunst in der Repräsentation der ungarischen Aristokratie'.

2 Burke, Changing Patrons.

3 Goldsmiths constituted probably the wealthiest strata of the Florentine artisan society. Yet, in the studied period, there were only three goldsmiths mentioned as speakers at the secret councils; Bonaccorso di Vanni, Betto, Domenico Dei. ASF, CP 22. fol. 86r (1383), fol. 92v (1383), fol. 118v (1383), CP 45. fol. 8v (1422). Prajda, 'Goldsmiths, Goldbeaters'.

4 For the merchant, Zanobi Gaddi, son of the painter Taddeo (c. 1300-1366) see: Mueller, 'Mercanti e imprenditori fiorentini a Venezia', pp. 9-10. For the social elevation of the family, from painters to businessmen see: Goldthwaite, The Building of Renaissance Florence, pp. 418-419. 
to establish a name for themselves by means of visual representation. The story of the Fat Woodcarver eloquently illustrates such intersections between artisan and merchant networks in early Renaissance Florence, hardly imaginable elsewhere in Europe at the time. ${ }^{5}$ These intersections developed into the main driving forces of Florentine artisan migration, an important feature in the spread of the Renaissance in Europe. Also, the protagonist of the anecdote, Manetto di Jacopo Amannatini, emigrated from Florence and matured into an architect in Pippo Scolari's service.

The Fat Woodcarver's story starts with the description of a dinner party, which probably took place in 1410, in the house of the respected citizen, Tommaso di Jacopo Pecori, back then Standardbearer of the urban militia (gonfaloniere di compagnia). ${ }^{6}$ The dinner company also included Giovanni di Bernardo Rucellai, descendant of a preeminent merchant lineage, the sculptor Donatello di Niccolò Bardi, and the architect Filippo di ser Brunellesco. ${ }^{7}$ The cooperation between these citizens of various social status - merchants and artisans - in playing the cruel joke on the Fat Woodcarver shows that outside of the norms and formalities that Florentines of a certain social standing might have kept in political and business lives, patrons and their clients occasionally socialized together. ${ }^{8}$ In fact, the Pecori and other Florentine families of some rank probably did not wish to marry their sons and daughters to artisans of far inferior social status, but they might have shared a dinner and engaged in informal discussions with them. Patrons might have even served as arbitrators in artisan marriages by facilitating the cementing of a social bond between two families. ${ }^{9}$

5 Manetti, Vita di Filippo Brunelleschi.

6 ASF, CP 40. fols. 116r, 126r, 13or, 132r, 135r. He had already died by the time of the first general census in Florence, and his sons' declaration shows no connection to any members of the company. ASF, Catasto 474. fols. 627r-631v. He spoke only in 1410 at the secret councils, in the same year when he was also elected to Standardbearer of the urban militia. The period of his office, between January and April, coincides with the possible time of Manetti's story. The Pecori and Giovanni di messer Niccolò Falucci were relatives, since Giovanni's daughter Alessandra married Luca di Francesco Pecori. Catasto 79. fol. 263r. Tommaso Pecori might have died not long before the first catasto, and his heirs shared properties with Luca di Francesco Pecori. Catasto 79. fol. 302r. Gabriello di messer Bartolomeo Panciatichi also married a Pecori girl. Catasto 297. fol. 357 .

7 In 1427, Giovanni di Bernardo Rucellai submitted his declaration with his cousin, the goldsmith Leonardo di Donato Rucellai. His company kept business ties with Masolino. ASF, Catasto 46. fol. 869v.

8 For an interpretation of the spatial dimensions of the joke, see: Atkinson, 'Getting Lost in the Italian Renaissance'.

9 Bender, Negotiating Marriage, pp. 190-229. 


\section{$1 \quad$ Goldsmiths}

By the first decades of the fifteenth century, Florentine goldsmithery had become a major competitor of the Sienese industry, the earliest centre of the sector in Tuscany. ${ }^{10}$ During the early Renaissance, goldsmiths constituted one of the most innovative groups among Florentine artisans; several important masters received training in goldsmiths' workshops. Among them, Donatello di Niccolò Bardi (1386-1466) and Lorenzo di Bartolo Ghiberti (1378-1455) grew into leading figures of the local goldsmith industry, while others like Filippo di ser Brunellesco, distinguished themselves with the design and construction of buildings.

Luxury items owned by the Scolari, as visual representations of their wealth and social status in Florence and Hungary, are known to us exclusively by archival sources. A couple of them refer to objects made of precious metals, which required goldsmiths' work, while others to silk textiles decorated with precious metal elements, also typically produced in goldsmiths' workshops at that time.

Rinaldo di messer Maso degli Albizzi, while visiting the estate of Ozora, mentioned the rich liturgical robes donated by Pippo Scolari to local religious places. He also detailed the expensive gifts they received with his fellow ambassador, on behalf of their hosts; among the gifts were carpets, a bathing shirt decorated with pendants, silver threads, and gilded silver buttons, and a small purse of gilded silver elements. ${ }^{11}$ Furthermore, one goldsmith's object might be connected to Pippo's person: a reliquary of the Holy Cross, which according to an earlier legend and a seventeenth century Florentine drawing, he ordered for the Holy Mary parish church of Impruneta, the most important religious place patronized by the Buondelmonti family. ${ }^{12}$ The story of the object is unknown, though the treasury of the church still houses a silver cross, datable to around 1425 and attributed to Lorenzo Ghiberti, which alludes to further existing networks of commission between leading Florentine goldsmiths and the Scolaris' inner network. ${ }^{13}$

In a similar fashion, written testimonials have survived about the expensive silk textiles and goldsmiths' objects owned by Matteo Scolari and his nuclear family. His purchases at a silk manufacturing company

10 Il Museo dell'Opera del Duomo, p. 5.

11 '.... Due tappetti di braccia tre l'uno, una camicia lunga da bagno di boccaccino, con fregi d'oro filato, e bottoni dalle maniche e dal collare d'ariento dorato [...]'. Commissioni di Rinaldo degli Albizzi, III. pp. 589-590.

12 Tarchi, 'Una lettera di Maria Maddalena d'Austria'.

13 Pisani, 'Il tesoro. Gli argenti', p. 62. 
show that his and his wife's garments included silk textiles of the finest quality. ${ }^{14}$ The supplies for his horse were similarly decorated with the finest silk fabrics. ${ }^{15}$ Besides the expensive silk clothing, Matteo and his wife also wore luxurious jewelry probably made by Florentine goldsmiths. Matteo's big silver belt might have been ornamented with the emblem of the guild he belonged to, a typical accessory of Florentine merchants of a certain social standing. His jewelry included a golden buckle and a ruby valued at 190 Florentine florins. Piera possessed jewelry made of three rubies and three pearls in the value of 300 Florentine florins. ${ }^{16}$ The latter might be identical to the shoulder brooch depicted by Fra Filippo Lippi in his Portrait of a Woman and a Man at a Casement, which might depict Francesca di Matteo Scolari as the main sitter. ${ }^{17}$ An inventory, made in 1425 , lists all the silverware found at that time in the Scolari palace, including silver plates of various sizes, tankards, pitchers, and a washbasin, all of them bearing the coat of arms of the family. The most expensive among them was a small casket, most commonly used for sweets and produced by a certain Dino goldsmith.

Andrea Scolari's testament reveals that during his life he considerably enriched the decorations of the various religious places under his protectorate. We learn about a carpet featuring the history of Saint'Apollonia, which he donated to a church near Varadinum (Oradea, RO). ${ }^{18}$ The carpet, similar to the silk textiles requested by Pippo for the funeral of Andrea and Matteo, might have been a product of one of the silk companies kept by

14 In 1423, Matteo purchased silk tetxiles for personal use from the company of Bartolomeo di Vieri, Francesco di Niccolò di Buto, Matteo di Niccolò da Cepetello, and Giulio and Giusto di Vieri di Guido: AOI, Estranei 188. fol. 35r.

15 AOI, Estranei 188. fol. $32 \mathrm{v}$.

16 'Una confecterìa grande con l'arme degli Scholari la quale fece Dino orafo, una cintola grande d'ariento casciano, due gobbelletti d'ariento dorati col coperchio et con l'arme, due miscirobbe bianche d'ariento con l'arme degli Scholari, uno bacino d'ariento biancho con l'arme, dodici schodelle d'ariento biancho, otto scodellini d'ariento biancho con l'arme, sei piattegli d'ariento biancho con l'arme, tre piattegli d'ariento un pocho minori senza arme, quatro piattelletti d'ariento, due gioielli l'uno a uso di messer Matheo con fibietta d'oro et uno balascio di valuta di fiorini centonovanta, et l'altro a uso di madonna con tre balasci e ttre perle di valuta di fiorini trecento.' For the original document, see: ASF, NA 5814. fol. 34v. The copy: ASF, Corp. Rel. Sopp. 78. 326. fol. 276r. For the publication of the inventory see: Prajda, 'A Scolari család és néhány jelentős firenzei textil- és ötvösműhely'.

17 Prajda, 'The Coat of Arms in Fra Filippo Lippi's Portrait'.

18 Andrea's testament: ASF, Corp. Rel. Sopp. 78. 326. fol. 29or. Published: Balogh, 'Andrea Scolari', p. 185. For summaries see: Zsigmondkori oklevéltár, XIII. doc. 42. Fraknói, 'Flórenczi András végrendelete', p. 120. 
the Scolaris' business partners. ${ }^{19}$ Besides the carpet, the reliquary of Saint Ladislaus, commissioned for the cathedral of Varadinum, burial site of the king, is datable to the period when Andrea served as the local bishop. Given the lack of any further written references on the reliquary, art historians placed the production of the object between 1406 and 1443. Ernő Marosi has proposed the 1420 s as the date of the reliquary, based on its stylistic connections to a group of sculptures from the royal court in Buda and to Pisanello's portrait of Sigismund of Luxembourg. He has also pointed out its stylistic similarities to Parisian goldsmiths' works, maybe as a result of Sigismund's attempt to attract French goldsmiths to Buda. ${ }^{20}$ According to Zsombor Jékely, the facial features of the reliquary correspond to 'an astonishing degree' to the head of Theseus on a copy of Masolino's lost cycle of the Famous Men, which the master painted in Rome after his return from Hungary. Therefore, the reliquary might have been completed around the time of Masolino's arrival in Hungary ${ }^{21}$ Similarly, the head of St. Ladislaus on the wall paintings of the chapel in Ozora resembles to some extent the reliquary and the previously mentioned image. The latter, as well as Andrea Scolari's, seal prove that besides Sigismund, the Scolari were also eager to advance the cult of the holy king and its sepulture. ${ }^{22}$ The reliquary is decorated with cloisonné technique, an innovation, that, according to Etele Kiss, might have arrived in the Kingdom of Hungary thanks to its Florentine inhabitants. ${ }^{23}$ In fact, the cloisonné technique had been used on goldsmiths' works in north Italian and Tuscan proveniences in the late fourteenth century. ${ }^{24}$ Reliquary busts, like the one of Saint Ladislaus, were also popular in Tuscany at that time. ${ }^{25}$ However, given the lack of further evidence, besides these historical and technical considerations, it would be challenging to make a direct connection at this point between

19 The Corsi-Melanesi company provided the silk textiles for the funeral. ASF, CS I. 229.

20 Marosi, 'Reformatio Sigismundi', p. 35.

21 Jékely, 'Masolino in Hungary', pp. 120-121.

22 Sigismund wished to be buried in the cathedral of Varadinum. Saint Ladislaus also appeared on Andrea Scolari's seal. Balogh, Varadinum, pp. 26-28. For the cult of St. Ladislaus's sepoltuary in Varadinum see: Fedeles, 'Ad visitandumque sepulchrum sanctissimi regis Ladislai'.

23 Kiss, 'Die Anfänge des Drahtemails', p. 281.

24 One of the earliest examples is the goblet of Gian Galeazzo Visconti at the treasury of the cathedral of Monza, which is datable to 1396. The workshop of Marco di Bartolomeo Rustici also used the enamel technique for decoration. See one of his commissions in 1453: 'Quattro candelieri di rame dorato con sei smalti l'uno nel piè e con lioncini [...]'. Cohn, 'Un codice', pp. 57-76.

25 Donatello himself prepared a reliquary bust of San Rossore (1424-1427) for the Ognissanti Church in Florence. 
the reliquary, the Scolari family, and any of the Florentine goldsmiths' workshops.

Goldsmiths surely were associated with the elite of Florentine artisan society by being enrolled, like silk manufacturers, into one of the five most prestigious guilds of Florence: the Por Santa Maria. ${ }^{26}$ Shared guild membership, as well as neighbourhood proximity, also favoured cooperation between goldsmiths' and silk workshops, which were located predominantly in the areas of Via Vaccareccia, Mercato Nuovo, and the Porta Santa Maria. The highest quality of silk cloth decorated with precious metal elements was the result of the fruitful collaboration between silk manufacturers, entrepreneurs, and goldsmiths' workshops. At that point, the Florentine precious metal industry relied exclusively on merchant networks that operated in the mining areas of Europe or they developed interests in extra-European territories. Among them, as we have already seen, the Scolaris' business network played an important role in transporting precious metals from the Kingdom of Hungary to the Italian Peninsula.

\section{Dino di Monte (1379-1431?) and Marco di Bartolomeo Rustici (1392/1393- 1457)}

In the 1420s, Baldinaccio di Catellino Infangati, Matteo Scolari's brother-inlaw, rented out his three workshops, located in Via Vaccareccia, to leading goldsmiths of the time. Among them was Dino di Monte (Montuccio), who, starting in 1403 , was a registered member of the Por Santa Maria Guild. ${ }^{27}$ The acquaintanceship between Dino and the Infangati brothers, however, went back at least a decade. By 1417, Dino's company had established a business relation with the Infangati brothers. ${ }^{28}$ Antonio Infangati had even ordered a silver belt from Dino for his personal use, which might have been similar to the one listed among the silverware of the Scolari palace. ${ }^{29}$ Dino also kept business contacts with other merchants belonging to the Scolaris' business network, like Ridolfo di Bonifazio Peruzzi. ${ }^{30}$ Dino

26 Prajda, 'Goldsmiths, Goldbeaters'.

27 ASF, Arte di Por Santa Maria 7. fol. 52r. (parish of San Lorenzo).

28 According to Antonio Infangati's account book, the intermediary bank which handled the transaction between him and Dino's workshop was Niccolò di Giovanni del Bellaccio's firm. ASF, Corp. Rel Sopp. 97. 13. fols. 2v, 3r-4r, 7r.

29 'Dino di Monte orafo e compagni deono avere a dì 31 di marzo per una cintola d'ariento biancho per me [...]'. ASF, Corp. Rel Sopp. 97. 13. fol. 3 r.

30 In 1427, his brother and Dino shared some businesses; Dino took silk textiles from the already mentioned workshop for Peruzzi. AOI, Estranei 188. fol. $331 \mathrm{v}$. 
also knew Matteo well, as it was Matteo who ordered silverware from the goldsmith, including the already mentioned small silver casket and several plates, all of them decorated with the coat of arms of the family, which was part of the furnishing of the Scolari palace. Besides his purchases, the two of them were probably engaged together in some business activity; following Matteo's death, Dino petitioned the Merchant Court demanding payment from the heirs for silver and other goods. ${ }^{31}$

By that time, Dino's goldsmiths' workshop was among the most respected ones and it might have also provided its leading masters with a fair living. Dino set up his partnership sometime before 1410, with a considerably younger goldsmith named Marco di Bartolomeo Rustici (Rustichi). ${ }^{32}$ In the 1420 s, the two of them had already been engaged in some entrepreneurial activity in the workshop by cooperating with the neighbouring silk manufacturing firms, which explains the frequent appearance of Dino and Marco's partnership in the account books of the nearby silk workshop run by Bartolomeo di Vieri, Francesco di Niccolò di Buto, Matteo di Niccolò da Cepetello, and Giulio and Giusto di Vieri di Vieri di Guido. ${ }^{33}$ This was also the very same silk firm that provided Matteo Scolari and his family with silk textiles. Since in 1420, it was Matteo's business partner Tommaso Borghini who introduced precious metal threads into the production of silk textiles in Florence, we should suspect that the threads were produced as an example in Dino's and Marco's workshop. After the 1430s, this continous demand from the silk industry gave rise to the foundation of a number of goldbeaters' workshops in the city, which replaced goldsmiths' work in the silk sector. ${ }^{34}$

Dino surely developed an economic relation with the other two neighbouring goldsmiths' workshops that rented their spaces from Baldinaccio Infangati. Giovanni di Bandino, the leading master of one of the workshops,

31 ' '...] Expone e dice Dino di Monte orafo in nome suo e di suoi compagni che l'erede di messer Matteo Scolari furono e sono loro debitori in fiorini 64 s. 4 d. 21 per arienti e mercatanti venduti e dati per esso Dino e compagni al decto per adietro messer Matteo [...]'. ASF, Mercanzia 7114bis. fols. 277v-278v. (1427) In 1427, Dino appears as creditor in the declaration of Matteo's heirs. ASF, Catasto 59. fol. 875r. Dino was included in Matteo's testament: ASF, Corp. Rel. Sopp. 78. 326. fols. 26or, $316 \mathrm{r}$.

32 ASF, Arte della Lana 543. fol. 7or. For Marco's tax declaration, submitted in 1427, see: ASF Catasto 50. fol. 561r. Cohn,' Un codice', p. 76. For Marco's life, see: Olive, 'Alla ricerca di Marco di Bartolomeo Rustici'.

33 Dino's company purchesed silk textiles from the workshop on a regular basis. AOI, Estranei 188. fols. 135r, 138r, 167v, 325v, 331v.

34 Prajda, 'Goldsmiths, Goldbeaters'. 
Figure 4 The Monastery of Santa Maria degli Angeli; on the right, the Scolari Oratory, by Marco Rustici, Rustici Codex, fol. 17v.

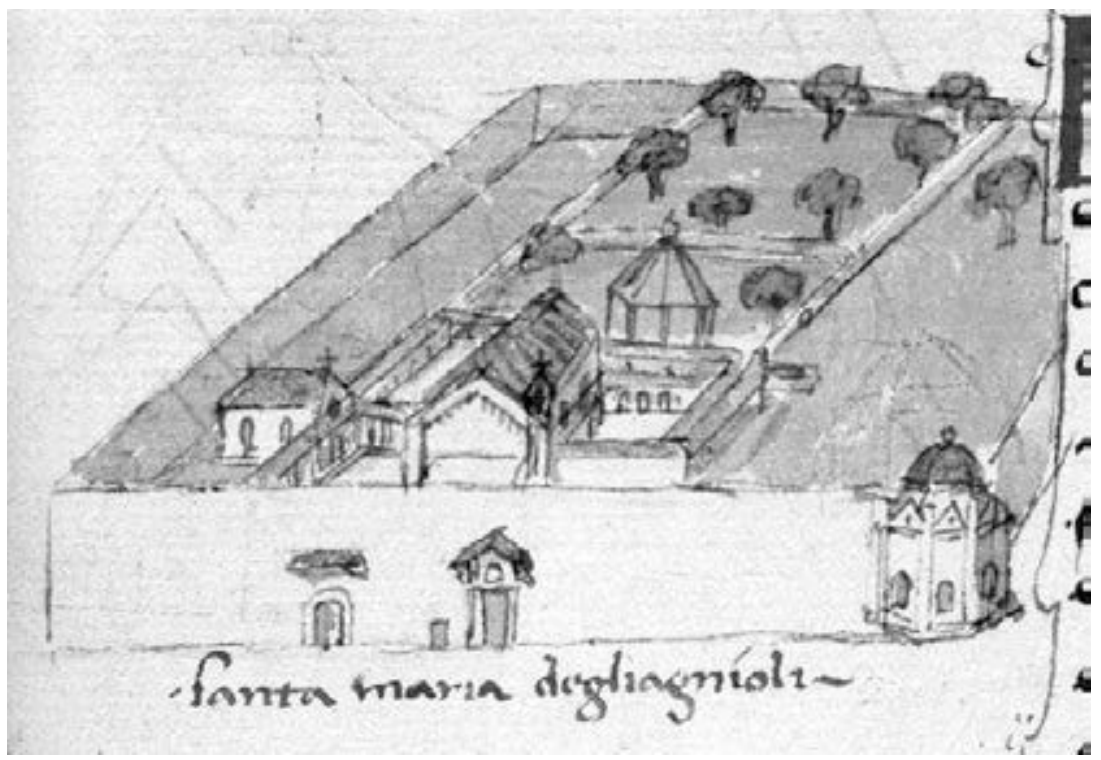

The publication of the image was authorized by the Biblioteca del Seminario Arcivescovile Maggiore di Firenze.

appears as a creditor in Matteo Scolari's tax declaration; he was also a customer of the Borghini silk firm. ${ }^{35}$ The third goldsmith, Michele di Sizzi (Zazzi, Sezi), was also a customer of the silk workshop run by Bartolomeo di Vieri, Francesco di Niccolò di Buto, Matteo di Niccolò da Cepetello, and Giulio and Giusto di Vieri di Vieri di Guido. ${ }^{36}$ Furthermore, even the priest of the Santo Stefano parish church in Tizzano, which was under Matteo Scolari's protectorate, made purchases from Michele's workshops. ${ }^{37}$ Antonio Infangati's fourth workshop was used by Piero di Giovannino, an embroiderer (ricamatore), who probably took care of the embroidery and other decorative elements of the silk textiles produced by the previously mentioned firms.

35 Giovanni appears as Matteo Scolari's creditor. ASF, Corp. Rel. Sopp. 78. 326. fols. 26or, 316r; MAP, 150.17 . fol. 19r. He bought textiles from Jacopo di Domenico Borghini for processing them. ASF, Arte della Lana 325. fol. 4ov.

36 AOI, Estranei 188. fol. 5or, 145r. Michele was the son of a tailor of German origins. Böninger, Die deutsche Einwanderung nach Florenz, pp. 147-148.

37 ASF, Catasto 69. fol. 171r. 
The close business relation between the workshop of Dino and Marco and the Scolaris' network is also manifested in Marco's major surviving work - the manuscript entitled La dimostrazione dell'andata del Santo Sepolcro - which he illustrated with a wide range of images of Florentine buildings. ${ }^{38}$ The high-quality drawings featuring on the first thirty pages of the codex, as well as some of Marco's other drawings, allude to a goldsmith master of significant talent. ${ }^{39}$ In addition to the drawings, the codex, datable to between the early 1440 s and around 1455 , contains short descriptions of the buildings, among them the Monastery of Santa Maria degli Angeli and the Scolari Oratory. This later one is the sole edifice the history of which was detailed at length by the author, stating that it was commissioned by the Bishop of Varadinum, 'Filippo Ispanne's relative, who administered the entire Kingdom of Hungary'. ${ }^{40}$ Interestingly, Marco, in his image of the Oratory, anticipated the completion of the building and therefore, according to Cristina Acidini, he would have been familiar with the original design of its master, Filippo Brunelleschi. ${ }^{41}$

\section{2 Architects}

In early Renaissance Florence, those artisans who designed and carried out building projects were originally trained in workshops of different sorts, most commonly as goldsmiths, sculptors, or woodworkers. In fact, no architect is known who might have emerged from the ranks of the masons. ${ }^{42}$ These workshops also played a crucial role in terms of networking among the young professionals and their future commissioners. In the first decades of the

38 Codice Rustici. For the dates of its execution: Olive, 'Alla ricerca di Marco di Bartolomeo Rustici', p. 43 .

39 The illustrations of Saint Augustine's life, written by a certain Andrea di Lorenzo, are also attributed to him. BNCF, Manoscritti, Fondo Nazionale II. I. 112. fols. 315r-v. (earlier: Fondo Magliabecchiano CI. XXXIX .3.). Dachs, 'Ein neues Blatt'. Lucia Gai claims that Marco might have occasionally practiced painting as well. In fact, he was planning to decorate his own burial chapel, which was meant to be located in the Santissima Annunizata church. Gai, 'La dimostrazione dell'andata dal Santo Sepolcro'.

40 'E in que luogo ordinò (un oratorio) il vescovo di Valadino cittandino fiorentino degli Scolari, parente di messere Filipo Ispanne, il quale ministrava tutto il reame d'Ungheria e gran battaglie fece per la fede di Cristo, tutte ebe vettoria contro al Gran Turco. Quello oratorio ò a otto face, con colonne, con molte capelle, e nel mezzo una trebuna tutta di macigno, lavorata tutta a l'antica, con perfette misure.' Codice Rustici, vol.1. fol. 18v.

41 Acidini, 'Un pio racconto', p. 15.

42 Goldthwaite, The Building of Renaissance Florence, p. 357. 
fifteenth century, private commissions were not at all widespread, or at least they are not well-documented. Many of the talented artisans-architects had the occasion to work only for corporate patrons, like the five major guilds.

\section{Filippo di ser Brunellesco Lippi, Brunelleschi (1377-1446)}

Filippo, by his training and thanks to his brothers' profession, was well connected to the city's goldsmiths' workshops, even to the ones related to the Scolaris' network. ${ }^{43}$ Because of his network and talent, Filippo had the possibility of working for both public and private commissioners. In 1419, he started the construction of the Ospedale degli Innocenti, which was under the supervision of the consuls of the Por Santa Maria Guild. The financial resources were left to the Guild by the testament of the wealthy merchant of Prato, Francesco di Marco Datini (1335-1410), who, having had no descendants, wished to preserve his name by the donation. ${ }^{44}$ A year later in 1420, Filippo and his former adversary, Lorenzo Ghiberti, were nominated together as the supervisors of the construction of Filippo's invention: the dome of the Florentine cathedral. ${ }^{45}$ The project was still ongoing when the master received the commission to design an oratory for the Scolari family.

In Florence, the custom of commissioning family chapels at various religious places dates back to the end of the thirteenth century. ${ }^{46}$ The Scolari's contemporaries, like the Brancacci and the Carnesecchi who obtained some wealth in international trade, erected family chapels mainly inside parish churches. However, the Scolari Oratory - like the Old Sacristy (1420-1428) of the Medici at the San Lorenzo Church and the Pazzi Chapel (starting from c.1429) at the Santa Croce Church, both designed and constructed by Filippo Brunelleschi - was meant to be an independent building, as part of the complex of the Monastery of the Santa Maria degli Angeli. ${ }^{47}$ The project,

43 He and his brother Tommaso were trained together as goldsmiths. Tommaso had even established a goldsmith company in Florence. ASF, Arte della Lana 326. fol. 28r (1405). Between 1400 and 1401, Piero di Giovannino and Lunardo di Mazzeo di Duccio were working on the San Jacopo altar in the cathedral of Pistoia. They employed the young Filippo di ser Brunellesco as their assistant. Gai, L'altare argenteo di San Jacopo.

44 Francesco left 1000 Florentine florins, while the Guild intended to spend more than 20,000 Florentine florins for the constructions. Battisti, Filippo Brunelleschi, pp. 46-68.

45 Haines, 'Myth and Management in the Construction of Brunelleschi's Cupola'. Battisti, Filippo Brunelleschi, p. 330. For the documents see: Krautheimer, Ghiberti, p. 406. Terenzi, 'Maestre e organizzazione del lavoro negli Anni della Cupola'.

46 Goldthwaite, The Building of Renaissance Florence, pp. 98-101.

47 For the description of its architecture, see: Battisti, Filippo Brunelleschi, pp. 248-256. 
therefore, was surely impressive, clearly mirroring the wealth as well as the inheritance strategy of the three elder Scolari.

Howard Saalman mentions the role Filippo di Rinieri Scolari played in administering his two uncles' inheritances, but he failed to attribute any task in planning the oratory to Pippo Scolari. ${ }^{48}$ In my opinion, the conditions of the donation mirror Pippo's intention to erect a family chapel to represent the wealth and fame of the family. Since Andrea, Matteo, and Pippo did not have any surviving male offspring, they might have had a plan comparable to that of Francesco Datini when they decided to leave a considerable part of the family patrimony in the hands of the Calimala Guild. The original wishes of Andrea and Matteo Scolari, expressed in their testaments, were to erect two separate monasteries in the centres of their estates in Tizzano and Vicchiomaggio, which would have been subjects of the Monastery of the Santa Maria degli Angeli. ${ }^{49}$ Both building complexes would have housed ten monks. The financial means were stipulated as 12,000 Florentine florins for each of them..$^{50}$ Andrea's testaments also explain that the sum should be spent on a monastery composed of a refectory and dormitorium, as well as on clothing for the monks. He also ordered a Bible for the monastery, specifying that it was supposed to be written in Gothic script..$^{11}$ In 1426, Pippo Scolari, probably acknowledging the likely high construction costs, asked the Pope for a year of patience in the execution of the two testaments. ${ }^{52}$ For the same reason, he also asked the Pope for a revision of the testaments, in order to unify the two heredities and construct a single building. ${ }^{33}$ The idea of the

48 Saalman, Filippo Brunelleschi, pp. 380-407.

49 See Matteo's testament in January 1424 . ASF, NA, 5814 . fol. $28 \mathrm{v}$. The copy of the document: ASF, Corp. Rel. Sopp. 78.326. fol. 272r. The reinforcement of Matteo's testament, in 1426: Corp. Rel. Sopp. 78.326. fol. 283v. Andrea's testament made in January 1426: Corp. Rel. Sopp. 78.326. fol. 289 r.

$50 \quad$ ASF, Corp. Rel. Sopp. 78. 326. fol. 256r.

$51 \quad$ ASF, Corp. Rel. Sopp. 78. 326. fol. 29or.

52 XV. századi pápák oklevelei, I. docs. 903-904.

53 In December 1427, the consuls of the Calimala Guild authorized the construction of a monastery either in Tizzano or in Vicchiomaggio. ASF, Provvisioni 118, fols. 134r-136v. Canestrini, 'Discorso sopra alcune relazioni'. Pippo requested a papal bull in order to be able to unify the two heredities. See the tax return submitted by the consuls of the Calimala Guild in the name of Matteo's inheritance, in 1431: 'Á si a dare Antonio di Salvestro di ser Ristoro fiorini 61o e costi di mesi 6, perchè a lui ciè, li trasse Francesco d'Altobiancho degli Alberti, che paghò a Roma per avere la bolla del papa, che di due luoghi si possa fare uno e altra grazia per fatti di messer Andrea Scolari, fu vescovo di Varadino ch'anche lui lasciò si faciese uno munistero di monaci di chamaldoli [...]'. ASF, Catasto 386, fol. 664r. For an account, prepared in 1427, which refers to the papal bull see: ASF, Corp. Rel. Sopp. 78. 326 . fol. 259r. Another document mentions the unification of the two heredities. Corp. Rel. Sopp. 78. 326. fol. 266r. 
oratory, therefore, would have been that of the baron, and even though Pippo died without seeing the first stone laid at the construction site, the agreement between the monastery and the Scolari family may have already been set. The monks were obliged to commemorate the days of Andrea's and Matteo's deaths. Furthermore, it was stated in the agreement that the oratory should be decorated with the coat of arms of the family. 54

The choice of the mother monastery, and therefore the location of the building, would have been the result of earlier connections the Scolari maintained with one of the most preeminent members of the monastery, Ambrogio di Bencivenni Traversari (1386-1439). The hypothesis advanced on Traversari's participation in the planning of the Scolari Oratory seems to be supported by further references. ${ }^{55}$ In 1424, Matteo Scolari decided to make a testament to include the Camaldolese monastery of the Santa Maria degli Angeli, in which he wished to leave 1000 Florentine florins to the place. $5^{6}$ The witnesses testifying the document were all local monks, including the miniator Simone Stefani (d. 1437) and Ambrogio himself. Ambrogio, who had been living within the walls of the Monastery since the turn of the century, appeared a year later once again as witness in Matteo's newly made testament. ${ }^{57}$ He stayed in the monastery until 1431, when Pope Eugenius IV made him general of the Camaldolese Order. In that year, a document issued prior to the beginnings of the constructions, stated that the Oratory should be designed in a way that the consuls of the Calimala Guild and the prior of the Monastery would like. ${ }^{8}$ Therefore, the project, which started in 1435, was watched over by the consuls of the Calimala Guild and Filippo di Rinieri Scolari, as well as Ambrogio Traversari.59 The construction of the oratory was disrupted in 1436, probably because of Ambrogio's absence when

54 'Et che in decto oratorio si metta l'arme degli Scolari e dell'Arte secondo parra loro [...]'. ASF, NA 10463. doc. 180. (31/08/1431) Pusblished: Saalman, Filippo Brunelleschi, p. 451. 'Item due anniversari ciascuno anno nel dì della morte del vescovo e di messer Mattheo [...]'. NA, 10465.

55 Von Fabriczy, Filippo Brunelleschi.

56 ASF, NA 5814. fols. 28r, 34r. (24/03/1425). The witnesses of the doucment were: Vieri di Giovanni Ser Riducci, Mauro Morelli, Cristofano Franceschi, the miniator Simone Stefani $(\dagger 1437)$, Raffaele Vieri, Salvestro Migliori, and Ambrogio di Bencivenni Traversari. In 1427, the Scolaris' heirs reported in their tax return that Matteo wished to leave 20 Florentine florins for the monks of the Santa Maria degli Angeli. 'I frati degli Agnoli devono avere, gli lasciò fiorini 20.' ASF, Catasto 59. fol. $875 \mathrm{v}$.

57 Pontone, Ambrogio Traversari, p. 1.

58 'Facciasi uno oratorio nel chanpaccio contiguo al muro dell'orto in quel modo e con quelle qualità che parra a consoli dell'Arte de Mercatandi e al priore di Sancta Maria degli Angeli [...]'. ASF, NA, 10463. doc. 180.

59 The two inheritances were consigned to Filippo Scolari. Saalman, Filippo Brunelleschi, pp. 385 . 
the Pope dispatched him to Fehérvár (Székesfehérvár; HU) to negotiate with King Sigismund.

Given Pippo's plans in founding a family chapel for symbolic reasons, it is very likely that he already had an eye on Filippo di ser Brunellesco as a possible architect of the building. So far no scholar has attempted to make a connection between the three elder Scolari and Brunelleschi, maybe because his name never appears in the documents related to the oratory before 1436 . Filippo, as we have seen, already had experience in designing private chapels. The Scolari as well as Ambrogio Traversari had the occasion to see the architect working, since the construction sites of both the Ospedale degli Innocenti and the Old Sacristy were located just a few steps away from the Monastery of the Santa Maria degli Angeli. Besides, in 1405, Matteo Scolari and the Lippi (Brunelleschi) brothers shared the neighbourhood, having been registered as inhabitants of the same parish of the Santa Maria Maggiore Church. ${ }^{60}$ Furthermore, Filippo's friendship with other artisans working for the Scolari family, including the already mentioned goldsmiths, also suggest that he was, indeed, acquainted with members of the family even before the commission. Filippo's biography, composed by Antonio di Tuccio Manetti (1423-1497), is supplemented by the already mentioned anecdote of the Fat Woodcarver, which describes how Filippo had humiliated his friend, the protagonist of the story, Manetto di Jacopo Amannatini. After the cruel joke, Manetto immigrated to the Kingdom of Hungary and received employment as Pippo Scolari's architect. ${ }^{61}$ The story, as we shall see later, is based on concrete historical facts, and therefore Filippo's friendship with the Fat Woodcarver might have given him the possibility of obtaining a commission from the Scolari.

\section{Manetto di Jacopo Amannatini, The Fat Woodcarver (1385/1387- 1450/1452)}

In early Renaissance Florence, another group of craftsmen in charge of building projects was trained as woodworkers: cabinetmakers and carpenters like Antonio di Manetto Ciaccheri (Manetti), who designed a wooden model for the dome of the Florentine cathedral as an adversary to Brunelleschi. ${ }^{62}$ The

60 ASF, Monte ser. II. 1805 . fol. 40.

61 'El Grasso, e l'compagno giunti in Ungheria si dettono da fare, et ebbonvi buona ventura, imperocchè in pochi anni vi diventarono ricchi secondo le loro condizioni, per favore del detto Spano, che lo fece Maestro Ingegnieri, e chiamasi Maestro Manetto da Firenze, e stettevi con buona reputazione [...]'. Manetti, Vita di Filippo Brunelleschi, p. 42.

62 Gli anni della cupola, o0204013.0430. (11/10/1432). Haines and Battista,'Un'altra storia', p. 20. 
Fat Woodcarver, Manetto di Jacopo Amannatini, might have been an artisan just like him. The story encapsulated in the Novella del Grasso legnaiuolo probably dates to 1410, when Pippo Scolari visited his native Florence as an ambassador of King Sigismund. This might have given Manetto the opportunity to follow his new master to the Kingdom of Hungary, where he was employed as the baron's architect. While there, his experiences were a far cry from the image depicted by Mary Bergstein: 'Compared with the forests of Central Europe, where the woodcarver Grasso ended up, Padua, with its university, its humanist culture, and its Florentine connections, must have looked like paradise. ${ }^{63}$ On the contrary, Donatello might have rightfully developed resentment toward Grasso, who, following Pippo Scolari's death, was employed in Sigismund's court in the company of several Florentines, humanists, and other prestigious foreigners. ${ }^{64}$

Manetto's financial conditions also point to a social status unique among leading Florentine artisans of the time. ${ }^{65}$ As Péter Farbaky's research has revealed, Manetto's case might have been the earliest, but it was definitely not the only one; another woodworker of Florentine origins named Chimenti Camicia (1431-c. 1505), was put in charge of the constructions and maybe even the design of buildings by Matthias Corvinus (r. 1458-1490). ${ }^{66}$

In the 1410 s and 1420s, the Scolari had important ongoing building projects both in Florence and in Hungary. By the time of Manetto's arrival in Hungary, the brothers had already moved their family home from the Via Panzano (today Via Panzani), located in the parish of Santa Maria Maggiore, to the more prestigious street of the Borgo degli Albizzi, the parish of San Procolo. ${ }^{67}$ According to the wine maker Bartolomeo di Michele del Corazza, in 1410, Pippo Scolari was staying in his own palace. ${ }^{68}$ The

63 Bergstein, 'The Fat Stonecarver', p.192.

64 In the Novella, Filippo di ser Brunellesco says to Grasso: 'You've really gotten rich out of it and become acquainted with the emperor of the world and with Pippo Spano and with many other great princes and barons.' Martines, An Italian Renaissance Sextet, p. 211. In fact, we find him in Buda in 1444 when he acted as one of the witnesses of the humanist Pier Paolo Vergerio's last will. Ziliotto, 'Nuove testimonianze'.

65 Prajda, 'Manetto di Jacopo Amannatini'.

66 Farbaky, 'Chimenti Camicia'.

67 See the tax declaration, submitted by the Scolaris' heirs in 1427: 'Una chasa posta in Firenze, nel popolo di San Brocholo, che da primo e secondo via, da terzo dette rede, da quarto chiasolino. Nella detta chasa abita Madonna Piera, dona fu di messer Mateo Scholari, colle sue figliuole e cholle maserizie a lloro uso.' ASF, Catasto 59. fol. 871r.

68 '[...] Questo messere Filippo tenne, il tempo che egli vi stette, corte bandita, e fece di molti e nobili conviti a cittadini e a donne, e quasi tutto Firenze traeva, sera e mattina; stava (a casa) sua dirimpetto a l'albergo della Corona, per modo che non vi si poteva capere.' Del Corazza, Diario fiorentino, p. 26. 
Figure 5 The castle, Ozora

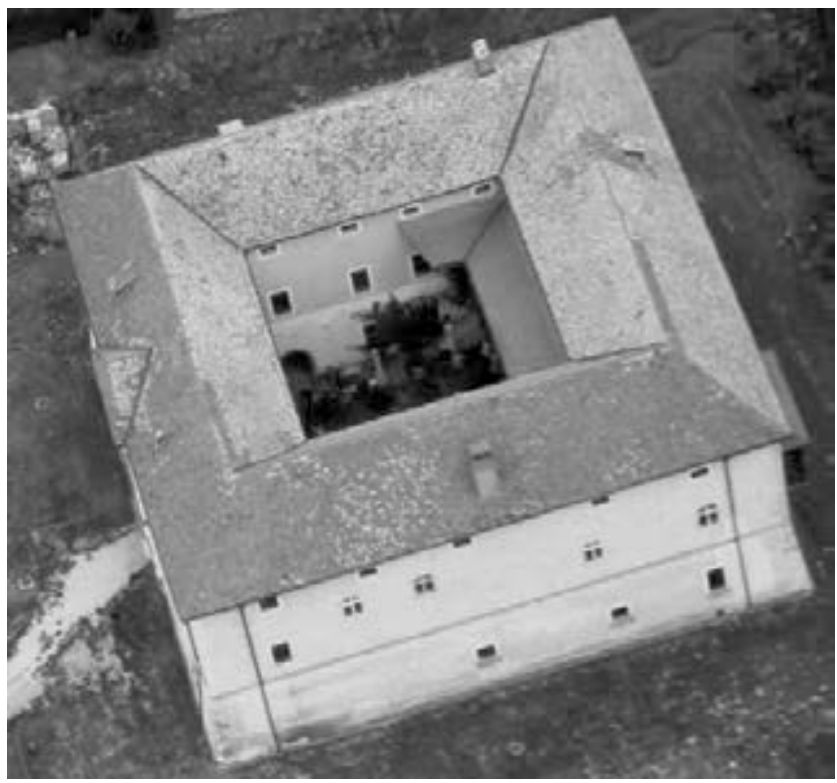

building in the Borgo degli Albizzi, mentioned briefly by another contemporary chronicle, was not entirely new, but it was constructed by its former owner, messer Gherardozzo Bartoli. ${ }^{69}$ However, Brenda Preyer, who has conducted extensive research on the history of the building, maintains that the original commissioners were the Scolari brothers. ${ }^{70}$ Either it was a new building, or it was just new to the Scolari, but the brothers definitely needed a skilled master to shape the palace according to their tastes. The Scolari palace itself, being a private property, has never been studied from an archeological-architectonical point of view. Only some elements of the first floor, marked by the appearance of the family's coat of arms on the façade, are seemingly datable to the Scolari period. ${ }^{71}$ Because of the lack of any research, the time of the construction of the inner, open courtyard is also uncertain. To what extent it may have shared elements with other palace buildings of the time, we do not know. Only short descriptions support the

69 'Chasa che fé murare Gherardozzo Bartoli et chiamasi quella di misser Matteo Scholari, ché llui vi lasciò dentro la moglie e le fanciulle femine [...]'. Petriboni and Di Borgo Rinaldi, Priorista, p. 209.

70 I wish to thank Brenda Preyer for sharing with me her observations and findings.

71 For the coat of arms of the family, see: Prajda, 'The Coat of Arms in Fra Filippo Lippi's Portrait'. 
idea that the palace was one of, if not the finest, in contemporary Florence and several preeminent guests of the Florentine Signoria sojourned within its walls..$^{72}$ Given the Scolaris' connections to various Florentine artisans, we shall not exclude the possibility that the architect of the Scolari Palace, as well as of their other building projects, might have been a noted one, if not Manetto himself.

In 1416, a couple of years following the Scolaris' displacement from the Via Panzano to the Borgo degli Albizzi, they received the royal privilege to erect a castle ('nobilium castra seu fortalitia') at the heart of Pippo's estates in Ozora, which might have been made of either stone or wood. ${ }^{73}$ Seven years later, in 1423, a document issued by King Sigismund informs us that he and his court were on a visit in Ozora. ${ }^{74}$ The King's presence in this small town of no strategic importance was definitely due to Pippo's invitation, and we might expect that, by then, the construction work on the castle was at least in a very advanced phase. Three years later, in 1426, the would-be-in-law Rinaldo di messer Maso degli Albizzi described the building as magnifico castello, an indicator that it was completed..$^{75}$ The ambassador also recalled in his report written to the Florentine Signoria that, while in Ozora, he met his fellow citizen, Manetto Amannatini, who, in spite of his Florentine origins, was called Manetto da Osora. ${ }^{76}$ The appellative was surely a result of Manetto's long stay in the baron's estate, and he, being a woodworker, would have participated in the construction work of the castle. His possible contribution is also supported by a short reference to a debt of the Scolaris' heirs toward Manetto, in which they owed him 1000 Florentine florins. ${ }^{77}$ In addition, the considerable increase of his savings and

72 In 1429, the prince of Salerno was among the guests. Del Corazza, Diario fiorentino, p. 70.

73 The royal privilage mentions three co-owners of the building: Pippo, Matteo, and their nephew and heir, Leonardo di Caccia Altoviti: 'Pipo, nec non Mathias et Leonardus, eoros heredes et successores [...]'. MNL, DL 87891 (16/04/1416), '[...] Castra, fortalitia seu castella lapidea vel lignea [...].' DL 87893. (27/05/1416).

74 Engel, C. Tóth, Itineraria regum et reginarum, p. 115.

75 '[...] Venimo a Osora, luogo principale dello Spano, messer Filippo Scolari conte di Temiscivara [...] e fececi mostrare il castello bellissimo [...]'. Commissioni di Rinaldo degli Albizzi, III. pp. 589-59o.

76 ' '...] Manetto da Osora, bene che sia fiorentino.' Commissioni di Rinaldo degli Albizzi, III. p. 590. On the basis of this evidence, Tibor Koppány developed the hypothesis that Manetto would have participated in the construction of the building. Koppány, 'Filippo Scolari ozorai vára'.

77 'Più capitoli di una lettera da Buda a dì 28 di giugno 1427 de fiorini 1000 si pagharono per messer lo Spano a Manetto di Jacopo da Firenze per lo lavorio del castel(lo) d'Osola.' ASF, Corp. Rel. Sopp. 78.326 . fol. $370 v$. 
outstanding credits over the years also prove that Pippo Scolari as architect in charge of construction works, in fact, employed him..$^{7}$

The main building of the castle in Ozora, which has been the subject of extensive archeological and architectonical research, also shared some elements with early Renaissance Florentine palaces and seigniorial buildings of the countryside. The chief archeologist of the site, István Feld, maintains that the castle follows the style of the buildings commissioned by King Sigismund in its carved details, including gates, doors, and windows. ${ }^{79}$ In my opinion, however, other features such as the rectangular and open inner courtyard surrounded by a series of rooms, the scarpata of the outer walls, and the Ghibelline-style merlatura can be considered as less typical of Hungarian castle-building of the period. Despite the stone components, the castle itself, as well as its surrounding walls and towers, was made of bricks. In fact, the single series of rooms organized around the open courtyard might give the impression of early Renaissance palaces. ${ }^{80}$ Meanwhile, the merlatura referred to the Ghibelline heritage of the Scolari, a typical element of fourteenth- and fifteenth-century castles in the Florentine countryside.

The building complex itself might have been the result of cooperation between local masons and stone carvers and a master mason or architect. As the examples of Antonio Ciaccheri and Chimenti Camicia show, woodcarvers might have indeed possessed the skills required to become the architect of a building of this size. The architect's role, as Richard A. Goldthwaite has defined, most commonly included administration and supervision of the production of materials for construction and the supply of equipment, as well as hiring and supervising workers. Therefore, management, technical

78 Prajda, Manetto di Jacopo Amannatini. The woodcarver was acquainted with members of the Scolaris' business network; salary and payment on behalf of Pippo Scolari was managed by the Carnesecchi. See his mother's tax declaration, submitted in 1427: 'Agiunse d' avere avere Manetto suo figliuolo da Simone di Pagolo Carnesechi e fratelli deono dare per la ragione d'Ungheria fiorini 120 di ungheri [...]'. ASF, Catasto 31, fol. 846r. Since 1437, his brother Niccolò was a member of the Doctors' Guild in Florence. ASF, Arte dei Medici e Speziali, 21. fol. 306r.

79 Feld, Az ozorai várkastély, pp. 8-9. Ibid., 'Die regelmäßigen ‘Burgschlösser' des Königreiches Ungarn'.

80 Goldthwaite, 'Florentine Palace'. Florentine palaces and building blocks in the 1427 Catasto are typically described as composed of casa or palagio, corte, pozzo; sometimes they included also loggias. Such buildings were owned, for example, by several inhabitants of the parish of San Piero Maggiore where the Scolari also lived. Among them were: Giovanni di Filippo Corbizzi (una chasa con torre, con corte, pozzo e volta) ASF, Catasto 8o. fol. 32v; Luca di messer Maso degli Albizzi (1 chasa, con corte, stalle e loggia) Catasto 80. fol. 45v. Tita, widow of Antonio d'Alessandro degli Alessandri, the Guadagni's in-law (1 palagio chon corte a volta, orto e stalle) Catasto 80 . fol. $67 \mathrm{v}$. 
skills, and a talent for designing buildings were the prerequisites. ${ }^{81}$ Because of the lack of any detailed evidence, we do not know which of these skills the woodcarver Manetto possessed.

However, besides the castle in Ozora, Pippo had several ongoing construction projects in the 1410 s and 1420 s which might have required Manetto's assistance. In 1418, he requested permission from Pope Martin V to build an Observant Franciscan convent, dedicated to the Virgin Mary, in Ozora. ${ }^{82}$ Three years later, in 1421, the convent was partly built, and by 1423 it was fully completed. ${ }^{83}$ During Sigismund of Luxembourg's reign, erecting convents in Hungary for Observant Franciscan friars came into fashion among the barons. ${ }^{84}$ In spite of the dubious chronology of the other convents built in the period, we can say that the convent in Ozora would have been one of the earliest used by the Observant branch of the Franciscans.

The Observants gained autonomy inside the Franciscan Order at the Council of Constance (1414-1418), in which some Hungarian barons, among them Pippo Scolari, participated. ${ }^{85}$ There are no documents at our disposal to determine whether Bernardino da Siena (1380-1444), an influential preacher of the Order who was present at the Council, might have had any direct connections to Pippo. However, his words would have generated the increased interest for the Observants; in 1417 and in 1424-1425, he was preaching in Fiesole and Florence.

The earliest notice with a direct link between the Scolari and the Observant Franciscans is related to Matteo Scolari's testament, issued in $1422 .{ }^{86}$ According to the document, he intended to make a donation for the construction of the earliest building of the San Salvatore al Monte in Florence. Furthermore, he wished to be buried on the property of the Observant Franciscans, located on the construction site of the San Salvatore

81 Goldthwaite, The Building of Renaissance Florence, p. 351.

$82 X V$. századi pápák oklevelei, I. doc. 95. The approval of the document arrived a day later: Zsigmondkori oklevéltár, VI. doc. 1961. (28/05/1418).

83 XV. századi pápák oklevelei, I. doc. 434. Zsigmondkori oklevéltár, VIII. doc. 1244. (15/12/1421). Fedeles and Prajda, Ő olyan vallásosan.

84 In 1409, János Maróthy received papal permission to erect a Franciscan convent. Because of his imprisonment he received a new permission in 1420 and started the constuctions in Gyula. The monastery was mentioned for the first time only in $145^{2}$. There is no information on when the Observant branch started to use it. Szatmári, 'Gyula középkori ferences temploma', p. 409. The King himself founded an Observant convent in 1421. Romhányi, 'Das Konstanzer Konzil und die Ankunft der Franziskaner-observanz'.

85 He was at the council of Constance in 1415, when the Franciscan observants obtained autonomy. He was mentioned by Ulrich von Richental. Chronik des Konstanzer Konzils, p. 182. 86 ASF, Corp Rel Sop. 78.326. fol. 267r. Koldulórendi építészet. 
near the San Miniato al Monte Monastery. He wanted to have his coat of arms carved on his sepulture and flags bearing his insignia hanging over the tomb. ${ }^{87}$

Similar to the convent in Ozora, the Franciscan Convent of the San Salvatore al Monte was founded in 1418 following the Council of Constance. In that year, the international merchant Luca di Jacopo della Tosa (Tosinghi) donated his properties, located near the San Miniato al Monte Monastery, to the order. The Della Tosa originally lived in the parish of San Salvatore, in the quarter of San Giovanni, which might explain the patron's choice of the new convent. Members of the Tosinghi family had business interests in Hungary, even setting up a merchant company with Matteo Scolari, sometime before $1408 .^{88}$ The construction work lasted between 1419 and 1435 , simultaneous with the erection of the convent in Ozora. ${ }^{89}$ Both convents can be considered among the earliest built for the Observant Franciscans in Florence and in Hungary.

In 1428, two years after his master Pippo Scolari's death, Manetto Amannatini returned to Florence to make his testament in the Convent of the San Salvatore al Monte. According to the document, he wished to leave a certain amount for the construction work of the building complex..$^{90}$ The witnesses of the testament were all Franciscan friars and at least one among them was originally from the Kingdom of Hungary. ${ }^{91}$

87 ASF, NA 5814. fol. 267 r. In his testament, dated to 1423 , he wished to donate 20 Florentine florins to the observant Franciscans. NA 5814 . fol. $28 \mathrm{r}$.

88 The tax declaration of Giovanni's heir and son, Scolaio, submitted in 1427: 'Dice che debbe avere fiorini 79 s. 15, i quali truova resta avere da Nofri di Andrea e Andrea di Giovanni e fratelli, sono per resto del chorpo della compagnia quando Giovanni Tosinghi fu loro chompagno in Ungheria, la quale compagnia finì nel'anno 1404 [...]'. ASF, Catasto 296. fol. 112v. Scolaio's declaration, presented in 1431. Catasto 381 . fol. 924r. In 1391, Giovanni Tosinghi was mentioned as collector of ecclesiastical revenues in Hungary. Esch, 'Bankiers der Kirche im Grossen Schisma', p. 382. In 1410, Branca di Rinieri Scolari owed a certain sum to Riniero and Scolaio Tosinghi. ASF, Diplomatico Normali, 08/10/1410. Giovanni Tosinghi operated in various parts of the Kingdom, including Transylvania. See a business quarel in which a merchant from Hermannstadt sued by his procurator, Giovanni di Pagolo Carnesecchi, Tosinghi's heirs for business debt: 'Johanni Tosinghi allora demorant nelle parti di Ungheria, venduti di decto Jacobo da Sibino, mercante nelle parti di Silvana del reame di Ungheria in più diverse et altri partiti tanta seta, panni e altre mercatantie di fi. 6400. s. 100.' ASF, Mercanzia 7119. fol. 393v.

89 Pellecchia Najemy, 'The First Observant Church'. For the donation of Luca della Tosa, cited by Pellecchia, see: ASF, NA 19337. fols. $45^{\text {r-v. }}$

90 In 1435, Tommaso di Francesco Busini donated the annual interest of his Monte shares of 1000 florins for ten years to the Franciscans in order to construct a family chapel. Pellecchia Najemy, 'The First Observant Church', p. 288.

91 ' [... Vocatis et rogatis fratribus Nicolao Benozi, Masseo Lapini, Antonio Ugolini, Iohanne Luce omnibus de Florentia, Nicolao Iohannis de Tripoli de Soria, Michaele Bartoli de Florentia, 
In the earliest phase of its construction, which falls in the first part of the fifteenth century, the building complex of the San Salvatore al Monte probably included only the area of the convent, the Busini Sacristy (1442), and a smaller church, the location of which is not identical to today's church. ${ }^{92}$ Meanwhile, the partial archaeological research, carried out in Ozora at the ruins of the convent, has revealed a church with three aisles, about 35-40m long and a convent of about 55-6om long. ${ }^{93}$ In the absence of similar archeological researches at the San Salvatore al Monte, we shall hardly be able to say to what extent the two building complexes shared architectural elements. The only surviving historical evidence seems to allude to the connection between the two convents in Florence and in Ozora, established by the Scolari family and maybe also by Manetto Amannatini as the possible architect.

\section{$3 \quad$ Painters}

Meanwhile in Hungary, patronizing parish churches situated on the feudum of a nobleman was a widespread practice. ${ }^{94}$ In Florence, too, parish churches located near houses of well-off merchants became places of artistic commission. ${ }^{95}$ Religious buildings of the time were most commonly decorated with wall paintings in Florence as well as in Hungary.

In Ozora, Pippo improved the parish church of the settlement with his donations as well as by renovating and developing the building itself, which was destined to be his burial site. ${ }^{96}$ Since the fifteenth-century building was replaced in the eighteenth century with a new one, and there has been no archeological research done on the site, it remains questionable if and how its walls were ornamented.

Besides the parish church, which was connected to the castle by a small bridge, Pippo also felt the moral obligation to build a chapel inside his

Benedicto Martini de Ungaria, Petro Laurentii de Gambasso, omnibus fratribus ordinis Beati Francisci de observantia vulgariter nuncupatis et aliter [...]'. ASF, NA 18510. Published: Prajda, 'Manetto di Jacopo Ammanatini'. I wish to thank Lorenz Böninger for calling my attention to the document.

92 For the groundfloor plans and the description of the archeological-architectonical researches and interventions see: Amonaci, Conventi toscani dell'osservanza francescana, pp. 172-173.

93 Nagy, 'Ozorai ferences'.

94 Jékely, 'Painted Chancels in Parish Churches'.

95 Najemy, A History of Florence, pp. 323-340.

96 Fedeles and Prajda, Ó olyan vallásosan. 
Figure 6 The head of Saint Ladislaus, frescoes at the castle chapel, Ozora

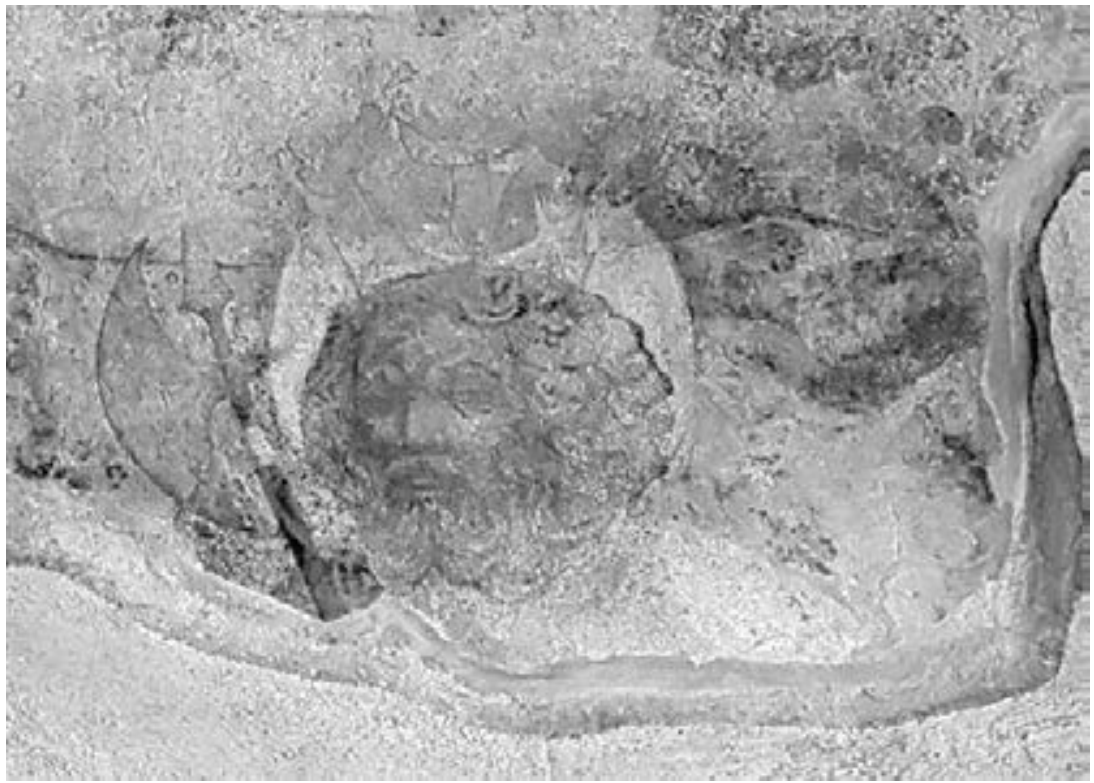

residence, which occupied the space between two sizeable halls on the first floor of the northeastern wing. It was first mentioned in 1438, when his widow, Borbála Ozorai, asked indulgence from the pope for her chapel, dedicated to San Filippo and Santa Barbara. 97 The fragmented paintings, found during the architectonical research of the northeastern wall, reveal that some parts or maybe the entire room was decorated with the alfresco technique. ${ }^{98}$ The high quality of the remaining face of Saint Ladislaus, as well as the technique itself, suggest that its skilled master might have been of northern Italian provenience. He painted the walls of the chapel during or right after the first construction phase of the building. ${ }^{99}$ Even

97 A középkori Magyarország levéltári forrásai, II. doc. (DL 88142).

98 Feld and Gere and Gerelyes and Kisfaludi and Koppány and Lászay and Vizi,Jelentés, pp. 87-88. I wish to thank István Feld for giving me access to the documentation of the architectonicalarchaeological research of the castle. The existence of the paintings has been mentioned so far only in brief. Feld, Az ozorai várkastély. For another short observation regarding the state of the frescoes, see: Szakács, 'Saints of the Knights', p. 321. A similar opinion was expressed in Jékely, 'Masolino in Hungary', p. 118.

99 Verebes, Ozora, p. 37. The restoration of the painting was carried out in 2002 by Dóra Verebes. I had the chance to see the fragments before the restoration, during the cleaning phase, and after the intervention. I wish to thank Dóra Verebes for giving me access to the documentation of the restoration. 
though the Italian master might not have been familiar with the figures of the Hungarian kings, Pippo's devotion to Saint Ladislaus required him to acquire some knowledge of his legacy. ${ }^{100}$

Among all these religious places, probably the most important constructions took place in Fehérvár (Székesfehérvár; HU), when Pippo received the royal privilage to establish a burial chapel in the cathedral. Since the beginning of the Hungarian Kingdom, this cathedral had accommodated the sepultures of several kings and queens, like the first king of Hungary, Saint Stephan, and Louis I of Anjou. ${ }^{101}$ It was not unique, but still a considerable honour among the barons, that Pippo obtained the right from Sigismund to construct a family chapel there, which was completed by $1418 .{ }^{102}$ Even though Pippo's and Borbála's sepulture was later destroyed, the inscription on their marble tomb was preserved by a Florentine chronicle. ${ }^{103}$

By the beginning of the fifteenth century, erecting private chapels inside both private homes and parish churches became very fashionable in Hungary as well as in Florence. Among the family chapels founded during Pippo's time, the one patronized by Pagolo di Berto Carnesecchi in the Santa Maria Maggiore Church, old parish of the Scolari, and another by Felice di Michele Brancacci in the Santa Maria del Carmine Church were both partly decorated by Masolino. ${ }^{104}$ The two commissions, by members of the mercantile elite, suggest that Masolino was among the most successful painters in the city at that time. The compilation of the Carnesecchi-Boni altarpiece in 1423 and his contribution to the decorations of the Carnesecchi Chapel (c. 1423-1425) might have given Pippo Scolari the confidence to offer him employment in Hungary. ${ }^{105}$

100 For the figure of Saint Ladislaus appearing in Italian paintings see: it appears on one of Simone Martini's paintings. Prokopp, 'Simone Martini Szent László képe Altomonte-ben'. For the cult of the holy King see: Kerny, Szent László-kultusz.

101 For example, Stiborici Stibor was buried there. Engel, 'Temetkezések'.

102 XV. századiszázadipápákoklevelei, I. doc. 78.Zsigmondkori oklevéltár, V. doc. 1858. Okmánytár Ozorai Pipo életéhez, p. 731.

103 'A dì 27 di dicembre al tempo di questi Signori morì in Ungheria Filippo Scolari al quale da l'Imperatore Sigismondo gli fu fatto una cappella et sepolcro di marmo con questo pitaffio latino et posto nella Propositura di Abba Reale. Sepulcrum egregi viri et magnifici domini Philippi de Scolaribus de Florentia Comitis Themisuariensis et Ozorum qui obiit. A.D. 1426 die 27 dicembris.' Petriboni and Di Borgo Rinaldi, Priorista, p. 193.

104 Joannides, Masaccio and Masolino, p. 28. The painting is decorated with the coat of arms of the Carnesecchi and the Boni families. In 1427, Pagolo's sons in their declaration wrote that: 'La chapella di Santa Chaterina di Santa Maria Maggiore de'avere per testamento di nostro padre ogni anno due torchi di valuta di fiorini tre.' ASF, Catasto 55. fol. 791r.

105 The Carnesecchi-Boni Madonna (Madonna of Humility) is the only panel painting by Masolino which has a solid chronology. Joannides, Masaccio and Masolino, p. 28o, cat. 4. Sometime 


\section{Tommaso di Cristofano di Fino, Masolino (1383/1384-1440?)}

Probably because of the great privilege and the extraordinary importance of the work, scholars have advanced the hypothesis that Masolino might have arrived in the Kingdom of Hungary in order to decorate Pippo's burial chapel in Fehérvár with wall paintings. Given the unfortunate condition of the remains of the cathedral and the lack of any written sources, we can only make speculations about the actual work carried out by the painter in Hungary. ${ }^{106}$ However, after visiting the chapel in 1426, Rinaldo degli Albizzi and his fellow ambassador described it as richly endowed and decorated. ${ }^{107}$

According to a hypothesis advanced by Anthony Molho, Masolino had already been decorating the Brancacci Chapel alone when he stopped his work and left for Hungary in September 1425. He stayed there for at least sixteen months, serving Pippo Scolari until December 1426. ${ }^{108}$ Wall paintings located in various parts of the former Kingdom of Hungary prove that the influence of the Italian Trecento had already reached the region. ${ }^{109}$ However, until Pippo's time, no Italian master, either architect or painter, working in the Kingdom of Hungary is known to us by name.

The obscurity of Masolino's early life makes it rather challenging to link him directly to any members of the Scolaris' network. Miklós Boskovits has suggested that the lack of any written documents on the painter in Florence prior to 1422 might be due to his absence from the city, and that he might have been active elsewhere, in Tuscany, in Lombardy, or perhaps even in Hungary. ${ }^{110}$ There are no sources which might confirm or deny Boskovits' hypothesis. However, it is likely that the Scolaris' merchant networks helped Masolino get to the Kingdom of Hungary. Maybe it was the Carnesecchi, old neighbours of the Scolari, who introduced them to the painter, we do not know exactly. ${ }^{111}$ Masolino also had some indirect connections to goldsmiths who were acquainted with the Scolari brothers. Paul Joannides maintains,

before September 1425, Masolino and Uccello decorated together the Carnesecchi Chapel in the Santa Maria Maggiore Church. In early 1427, it was noted as complete. Idem, p. 30.

106 Jékely, 'Masolino in Hungary', pp. 119.

107 '[...] E vedemo la capella sua fatta di nuovo, per sua sepoltura, adorna molto, e bene dotata e e di ricchi paramenti.' Commissioni di Rinaldo degli Albizzi, III. pp. 589-590.

108 Molho, 'The Brancacci Chapel'. The only document testifying Masolino's presence in the Church of the Santa Maria del Carmine is datable to July 1425. Beck, Masaccio, p. 5 o.

109 Prokopp, Italian Trecento Influence on Murals in East Central Europe.

110 Boskovits, 'Il percorso di Masolino', pp. 48-49.

111 For the Carnesecchi Chapel, see: ' [...] Cappellae et altaris Sanctae Catharinae erectae et factae per dictum olim Paulum patrem ipsorum in eccelsia Sancta Mariae Maioris de Florentia (1427).' Procacci, 'Sulla Cronologia', pp. 37-38. 
on the basis of stylistic inference and a critical reading of Giorgio Vasari's Vite, that Masolino 'certainly would have had some training before 1403, in all probability as a silversmith' and that he was an apprentice in Lorenzo Ghiberti's workshop as well. ${ }^{112}$ In my view, the multiple cross-references to goldsmiths, including Dino di Monte and Leonardo di Donato Rucellai, members of Giovanni Rucellai's household, who appears as Manetto Amannatini's friend in the story of the Fat Woodcarver, support the idea that Masolino was closely related to these goldsmiths' workshops. ${ }^{113}$

Furthermore, the Florentine merchants involved in his payment also underline that the painter was indeed acquainted with members of the Scolaris' business network. The mediating company between the baron and Masolino was the one run by Simone di Piero Melanesi and the Corsi brothers in Buda, which had received the Monte payment on Pippo Scolari's behalf. ${ }^{114}$ On 26 August 1426, Pippo deposited the sum of 799 Florentine florins, 6 soldi, and 8 denari to Piero di messer Donato Velluti. ${ }^{115}$ At the termination of the contract period, one out of the following Florentines - Manetto Amannatini, Nofri di Bardo Bardi, messer Giovanni di Piero Melanesi, Antonio di Piero Fronte, Ridolfo di Bonifazio Peruzzi, or Filippo di Simone Capponi, all of them important members of the Scolaris' network - was supposed to confirm that the painter had carried out the commission. In the end, it fell to Filippo Capponi to provide proof of the compilation of the contract

112 Another artisan, named Bernardo di Piero Ciuffagni (1385-1457), was associated with Ghiberti's workshop. Krautheimer, Ghiberti, pp. 369-370. doc. 31. In 1422, Masolino rented a house together with Ciuffagni. Joannides, Masaccio and Masolino, p. 28. They were both connected to the Por Santa Maria Guild; as Bernardo was a member of the Por Santa Maria Guild. ASF, Arte di Por Santa Maria 28. So did Masolino's grandfather, Fino, who was a goldsmith. Procacci, Massaccio, pp. 13-14. In 1427, Bernardo's tax return mentions an outstanding credit in Dino di Monte' name. ASF, Catasto 23. fol. 451v. Masolino was a debtor of Leonardo di Donato Rucellai's workshop. Catasto 46. fol. $869 \mathrm{v}$.

113 See the notes above. Leonardo Rucellai sued Masolino together with another painter at the Merchant Court on 25 January 1427. Beck, Masaccio, p. 51.

114 The circumstances of his payment are detailed in the documents published in Molho, 'The Brancacci Chapel'. See the declaration of Masolino's mother, in 1427: 'Tomaso suo figliuolo sta in Ungheria dicesi dovere avere certa quantità di danari dal erede di messer Filippo Scholari, non è chiarito il che e però non visi da. Sono fi. $360 \mathrm{~s}$. di Monte comune che ànno inseritti in Simone Melanesi e Simone e Tommaso Corsi.' ASF, Catasto 30. fol. 253 r.

115 In 1378, he lived in the neighbourhood of twelve with his brothers, Michele and Biagio. Piero's son, Donato, in 1433 had a banking company under his name with Giovanni Rondinelli. ASF, Catasto 433. fol. 327r. Piero's two sons, Guido and Tommaso, were registered as goldsmiths in 1426 and in 1428. ASF, Arte di Por Santa Maria 7. fol. 8or. In 1431, Baldassare di Antonio Santi, business partner of Matteo Scolari, said that he needed to clarify his account with the heirs of the company of Piero Velluti. Catasto 380 . fol. $305 \mathrm{v}$. 
in the presence of other Florentine businessmen: Giuliano d'Amerigo Zati, Manetto di Bernardo Amidei, and Biagio di Antonio Spini. ${ }^{116}$

Besides the frescoes of the chapel in Ozora, which clearly do not show any significant similarities to Masolino's style, no other paintings can be connected to the Scolaris' patronage in Hungary. Scholars might be left rightfully puzzled by the fact that while Masolino was working in Pippo's service, another master oversaw the decoration of the chapel in his castle. ${ }^{117}$ The style of the wall paintings, as far as the fragments allow us any speculation, points toward the Venetian provenience of the master. The settlement of the Scolaris' nephews in the city might also contribute to the hypothesis that Tommaso had the chance to collaborate with painters of Venetian origin. Furthermore, at the same time that Masolino left for Hungary in September 1425, his former fellow painter, Paolo Uccello (1396/1397-1475), with whom he worked on the Carnesecchi Chapel, departed for Venice, where he stayed at least until $1427 \cdot{ }^{118}$ It was customary at that time that painters did not work alone; they employed assistants or even other masters in completing a commission. Therefore, Uccello or the Scolaris' network in Venice might have helped Masolino to find an assistant of Venetian origins.

Even though Masolino's original three-year contract ended with Pippo Scolari's death, the painter did not return to Florence immediately, or at least not until July $1427 .{ }^{119}$ Zsombor Jékely has suggested that Masolino might have worked elsewhere in Hungary, for example, in the court of the Bishop of Varadinum, Giovanni Melanesi. ${ }^{120}$ Given the termination of his employment far before the preliminary negotiated contract period, we can expect that Masolino indeed tried to seek employment elsewhere in Hungary

116 Molho, 'The Brancacci Chapel', p. 94. In 1433, Giuliano and Niccolò d'Amerigo Zati were running a business firm in Hungary. ASF, Catasto 453. fol. $824 \mathrm{r}$.

117 Members of the Scolaris' network maintained strong connections with Florentine painters. Among them, Giovanni di Gherardo Buondelmonti, who lived for years in the Kingdom of Hungary, rented out his two workshops to painters Marco del Buono and Salvestro di Dino in 1427. See Giovanni's tax return: ASF, Catasto 38. fol. 327r.

118 Paolo Uccello's frescoes of the Annuntiation, dated to $1424 / 1425$, have consequently been destroyed. There are no written sources to verify that Masolino and Paolo Uccello, indeed, worked simultaneously on the Carnesecchi Chapel. Masolino, Storie di San Giuliano. Before 1407, Uccello, Donatello, and Ciuffagni were all registered in Ghiberti's workshop as assistants. Krautheimer, Ghiberti, I. p. 404.

119 Beck, Masaccio, pp. 51-52.

120 In support of his thesis, he referred to a debt of 133 Florentine forins which the Menalesi firm owed to Masolino. He also cited a lost image of Masolino, which might have resembled the reliquary of Saint Ladislaus, kept in the cathedral of Varadinum. Jékely, 'Masolino in Hungary'. 
to make his stay as worthwhile as originally planned. However, because of the lack of any written evidence we can only speculate on where he might have spent the time between December 1426 and July 1427 .

Upon his return to Italy sometime after June 1427, Pippo's acquaintanceship with Branda Castiglione, former papal legate in Hungary, helped Masolino to obtain a commission from the cardinal in Italy. ${ }^{121}$

121 On Branda see: Zsigmondkori oklevéltár, II. doc. 7917 (1410). Joannides, Masaccio and Masolino, p. 34. The scarcity of archival evidence on Masolino does not allow us to establish further connection between the painter and other artisans and patrons. 